are interested in huge datafiles for many users; the only successful scholarly databases have been taxsupported.

Leslie Hume of the Research Libraries Group also spoke of the proliferation of very specialized scholarly databases and about the need for comprehensive sources or indexes to make these accessible. She sees a need for databases with an interdisciplinary focus, for more archival repositories in electronic form, and for more access to visual materials. She reiterated the need for institutional funding, since scholarly databases are not revenueproducing.

What emerged from these meetings was that European libraries are exploring the sharing of resources, mostly within their own boundaries, but that national libraries are contending with problems of increasing regional ethnic focus. It is clear that in Europe, as in the U.S., that new technology is forcing librarians to make hard choices. The Europeans are trying to make appropriate and financially possible selections of electronic technologies, but are finding difficulties with incompatible hardware and rapidly changing products.

Most Continental librarians continue to see their role as curatorial; however, they do not aim at completeness of collections as do American research librarians. In fact, the idea of a complete collection appears unrealistic to European librarians, as indicated by the discussion at the session on "The Conspectus as a Collection Management Tool for Western European Studies."

All in all this first overseas ACRL conference was both enlightening and stimulating. U.S. librarians found much to exchange with others from their own country as well as with the Europeans. As always, the informal exchanges were as valuable as the working sessions.

Florence was an ideal choice for a site, although perhaps too seductive a city for conferees. It took real strength of character to resist the lure of the museums, churches, and Renaissance streets in favor of meetings. And the hospitality (repasts and entertainment) arranged by Mario Casalini of Casalini Libri was superb - probably never again will a library conference offer such feasts in such elegant surroundings.-Claire Dudley, Science and Nonprint Editor, Choice, Middletown, Connecticut.

\title{
RTSD preservation microfilming institute at Yale University
}

For two and a half days, April 21-23, 1988, over 110 librarians and archivists met at Yale University for a program entitled "Preservation Microfilming: Planning \& Production," a regional institute sponsored by the ALA Resources and Technical Services Division's Reproduction of Library Materials Section. The Institute was a follow-up to their earlier institute, "Preservation Microfilming: Administrative Issues," held in March 1986. Both programs were planned in order to meet the training needs of libraries currently or prospectively involved in preservation microfilming. The recent institute was designed to provide practical information and training to those responsible for microfilming programs.

Following welcoming remarks by Yale University librarian Millicent Abell, Wesley Boomgaarden, preservation officer at the Ohio State University Libraries, spoke on the elements in the preservation microfilming process and their interconnections to the library's preservation activities and other operations, such as collection development and providing bibliographical control. Boomgaarden also discussed such "macro-issues" as the institutional planning process, cost control, technologies to consider, and the effect on the library users.

To ensure that microfilm will provide a permanent copy, libraries must meet many special stan- dards and specifications in the preparation, production, duplication, and storage of the microfilm. Myron B. Chace, head of the Special Services Section, Photoduplication Service, at the Library of Congress, reviewed many of the standards and specifications in the filming process, providing some insights into their development.

A key part of the Institute was four preparation workshops, each focusing on a different type of material: monographs, serials, newspapers, and manuscripts and archives. Each of the workshop leaders described key steps in the preparation process: searching available records to determine the existence of other microform or hard copies; the physical examination and preparation of material; the physical preparation of the items to be filmed, including collation, targeting, and reel programming; film inspection and other post-filming procedures. The workshop leaders for these sessions were Sherry Byrne, preservation librarian, the University of Chicago Library (Monographs); Tamara Swora, assistant preservation microfilming officer, Preservation Microfilming Office, the Library of Congress (Serials); Ann Swartzell, associate librarian (Conservation), New York State Library (Newspapers); and Vanessa Piala, head of preservation services, Smithsonian Institution Libraries (Archives and Manuscripts).

Participants had the opportunity to see such 
preparation and filming in progress during several tours. In addition to a tour of the Yale University Library Microfilming Unit, the group viewed the facilities for contract filming at Micrographics Systems of Connecticut and the micropublishing plant of Research Publications, Inc.

The program concluded with the presentation of papers addressing key issues in moving the national preservation effort forward. Margaret Byrnes, head of the Preservation Section, National Library of Medicine, reviewed some of the factors to consider in making a decision between doing microfilming in-house and contracting for filming with a service bureau. Patricia McClung, associate director for program coordination, Research Libraries Group, Inc., discussed the process of identifying and monitoring the costs of microfilming, referring to the results of surveys of research libraries with active filming programs. After defining cooperation as "a dynamic state of institutions working to- gether for sufficient mutual benefit to outweigh the disadvantages," Carolyn Harris, assistant director for preservation, Columbia University Libraries, analyzed the issues to be considered when establishing a cooperative program, using some existing programs as models. Gay Walker, head of the Preservation Department, Yale University Library, wrapped up the institute with visionary remarks. She looked forward to the day when a network of regional centers would ensure that the materials documenting our civilization are being preserved through microfilming. More importantly Walker saw the use of an older technology, microfilming, for permanent preservation, running simultaneously with the newer digitization technologies to provide open and comprehensive access to the content of the materials - regardless of the scarcity or condition of the original-to all library users.Karen Muller, Executive Director, RTSD.

\section{Man arrested as suspect in thefts of rare materials}

Los Angeles police are investigating the activities of a man discovered in a closed stack area of the University of California-Riverside Library in connection with the thefts of more than $\$ 1$ million in materials from university libraries on the West Coast. The man, identified as Mathew McGue, 40, was arrested April 18 after a custodian twice discovered him in the special collections area on the third floor of the library. Although no items were apparently missing from the UCR library, McGue was arrested and cited on suspicion of trespassing and possession of burglary tools (both misdemeanors) and released on his own recognizance.

At least three libraries have had large numbers of books and manuscripts stolen recently, including Claremont College (more than $\$ 1$ million), the University of Oregon $(\$ 217,000)$, and Washington State University $(\$ 200,000)$. Materials from the 15 th and 16th century have been the major targets, although the missing holdings from Oregon are primarily letters, diaries, railroad records, stock certificates, and Indian treaties documenting the state's 19th-century history.

The thefts appear to have been carefully planned. In each case the stolen items were kept under lock and key in non-public areas. The thefts have also been exceptionally selective, indicating a high degree of familiarity with each of the collections.

The suspect was apparently representing himself to Riverside library staff as a University of Minnesota associate professor of psychology named Matthew McGue in order to gain access to special collections. $\mathrm{He}$ is a male Caucasian with thinning, grayish-brown hair and a slim build, 5 feet 8 inches tall.

Anyone with information regarding this person or his activities should contact Sheryl Davis, Assistant to the University Librarian, University of California-Riverside, P.O. Box 5900, Riverside, CA 92517; (714) 787-3221.

\section{Intellectual Freedom Award}

Nominations for the 1988 Robert B. Downs Intellectual Freedom Award are being accepted by the University of Illinois Graduate School of Library and Information Science. The award recognizes individuals or groups for their efforts to oppose censorship or to further intellectual freedom in libraries and information centers. It carries with it a $\$ 500$ prize funded by Greenwood Press, of Westport, Connecticut.

Last year the honor went to Gene D. Lanier, director of graduate studies in the Department of Library and Information Studies at East Carolina University.

The award was established in 1968 to honor Downs, who is widely known as a crusader for intellectual freedom. A distinguished author, educator, and administrator, he served as director of the University of Illinois Library and Library School from 1943 to 1958, and dean of library administration from 1958 to 1971 . He is now dean emeritus of library administration.

Letters of nomination, which will be considered until October 1, may be sent to: Leigh Estabrook, Dean, University of Illinois Graduate School of Library and Information Science, 410 David Kinley Hall, 1407 W. Gregory Drive, Urbana, IL 61801; (217) $333-3280$. 


\section{New Journals From \\ Cambridge!}

\section{Visual Neuroscience}

Editor:

Katherine V. Fite

Visual Neuroscience publishes high-quality research and theoretical articles with primary emphasis placed upon studies which address the retinal and brain mechanisms that underlie visually-guided behaviors and visual perception.

Visual Neuroscience (ISSN 0952-5238) is published quarterly. Subscription to

Volume 1,1988 is $\$ 100.00$.

\section{The Journal of Economic History}

\section{Editors:}

Claudia Goldin \&

Paul Hohenberg

\section{The Journal of Economic} History, published by Cambridge University Press from 1988, is devoted to the interdisciplinary study of history and economics and covers abroad scope including both method and geography.

The Joumal of Economic History (ISSN 0022-0507) is published quarterly. Subscription to Volume 48, 1988 is $\$ 40.00$

\section{Polar Record}

Editor:

Bernard Stonehouse

Now published by Cambridge University Press, Polar Record, a crossdisciplinary journal, publishes articles and notes on all subjects of polar exploration and research, both current and historical.

Polar Record (ISSN 0032-2474) is published quarterly. Subscription to Volume 24,1988 is $\$ 70.00$.

\section{International Industrial Biotechnology}

\section{Editors:}

Roger Gilmore,

Roderick Greenshields, John Higgin \&

Chistopher Lowe

International Industrial Biotechnology, relaunched in 1988 by $\mathrm{Cambridge}$ University Press, presents valuable information to people working both in the professional and academic worlds and is unique in its attempts to interface the two worlds.

International Industrial Biotechnology (ISSN 0269-7815) is published bimonthly. Subscription to Volume 8 , 1988 is $\$ 99.00$.

\section{The New Phytologist}

Chief Editor:

D. H. Lewis

Since its inception in 1902, The New Phytologist has grown to be a premier botany journal. From 1988 it is published by Cambridge University Press. Its monthly issues include research notes, review articles and book reviews on all aspects of the plant sciences.

The New Phytologist (ISSN 0028$646 \mathrm{X}$ ) is published monthly.

Subscription to Volumes 108-110, 1988 is $\$ 395.00$.

\section{The Knowledge Engineering Review}

Editor:

John Fox

The Knowledge Engineering Review is a high quality journal committed to the critical development of Artificial Intelligence, the clarification of its methods and concepts, and the dissemination of mature knowledge to those who need it.

The Knowledge Engineering Review (ISSN 0269-8889) is published quarterly. Subscription to Volume 3, 1988 is $\$ 98.00$.

\section{Send Orders to:}

